\title{
Finite Element Analysis of Wood Materials
}

\section{Analiza drvnog materijala metodom konačnih elemenata}

\author{
Review paper $\bullet$ Pregledni rad \\ Received-prispjelo: 17. 12. 2012. \\ Accepted-prihvaćeno: 9. 4. 2014. \\ UDK: $630 * 812 ; 630 * 824 ; 630 ; 836$ \\ doi:10.5552/drind.2014.1254
}

\begin{abstract}
Continuous quality and reliability improvement of computers as well as their widespread application in design of furniture industry encourage the elaboration of optimization algorithms of furniture constructions, in which rigidity characteristics of the applied joints would be taken under consideration. In the last four decades, the finite element method, FEM, has become the dominant technique used for analyzing physical phenomena in the field of structural, solid and fluid mechanics as well as for the solution of field problems. This paper gives a bibliographical review of the FEM applied in the analysis of furniture products constructed with wood. The following topics are included: Wood as a furniture construction material and its mechanical properties. It is, therefore, reasonable to replace statistical methods of furniture optimization, which have been applied so far, by gradient methods which allow obtaining much more precise results.
\end{abstract}

Key words: wood, Finite Element Method, numerical analysis

SAŽETAK • Kontinuirano poboljšanje kvalitete i pouzdanosti računala, kao i njihova široka primjena u industrijskom dizajnu namještaja, potaknuli su razradu algoritama za optimizaciju konstrukcija namještaja, u kojima se posebno razmatra krutost primijenjenih spojeva. U posljednja četiri desetljeća metoda konačnih elemenata (FEM) postala je najčešća tehnika za analizu fizikalnih pojava na području strukturne mehanike, mehanike čvrstih tvari i fluida, kao i za rješavanje problema na tim područjima. U tekstu se daje bibliografski pregled primjene metode konačnih elemenata u analizi namještaja proizvedenoga od drva. Pritom je obuhvaćena tema drva kao konstruktivnog materijala za namještaj i njegovih mehaničkih svojstava. Dokazano je kako je razumno umjesto dosad primjenjivanih statističkih metoda optimizacije namještaja primijeniti gradijent-metode koje omogućuju dobivanje mnogo preciznijih rezultata.

Ključne riječi: drvo, metoda konačnih elemenata, numeričke analize

\section{INTRODUCTION \\ 1. UVOD}

The finite element method (FEM) is the dominant discretization technique in structural mechanics. The basic concept in the physical interpretation of the FEM is the subdivision of the mathematical model into disjoint (non-overlapping) components of simple ge- ometry called "finite elements" or elements for short. The response of each element is expressed in terms of a finite number of degrees of freedom characterized as the value of an unknown function, or functions, at a set of nodal points. The response of the mathematical model is then considered to be approximated by that of the discrete model obtained by connecting or assembling the collection of all elements. The disconnection-

\footnotetext{
${ }^{1}$ Authors are professors at Forest Industry Engineering Department, University of Bartin, Turkey. ${ }^{2}$ Author is professor at Material Processing Department, Bülent Ecevit University, Turkey.

${ }^{1}$ Autori su profesori Odsjeka za industrijsku preradu drva, Sveučilište u Bartinu, Turska. ${ }^{2}$ Autor je profesor Odsjeka za obradu materijala, Sveučilište Bülent Ecevit, Turska.
} 
assembly concept occurs naturally when examining many artificial and natural systems. For example, it is easy to visualize an engine, bridge, building, airplane, or skeleton as fabricated from simpler components. Furthermore, FEM has become a powerful tool for the numerical solution of a wide range of engineering problems. Applications range from deformation and stress analysis of automotive, aircraft, building, and bridge structures to field analysis of heat flux, fluid flow, magnetic flux, seepage, and other flow problems.

The main postulate of FEA is that complex domains can be discretized and represented by an assembly of simpler finite sized elements. This enables description of the global problem via a system of differential equations that account for inter element compatibility and boundary conditions requirements. The concepts, fundamentals and application of FEA are described in detail in many texts (Tanvir and Utku, 1987; Bathe, 1996; Cook, 1981; Zienkiewicz and Taylor, 1988; Zienkiewicz and Taylor, 1989). The tedium of handling the data and the possibility of errors creeping in as the number of elements increase are discouraging factors for the finite element analyst (Chandrupatla and Belegundu, 1991).

The aim of the bibliographic review is to research with FE method applied to the analyses of wood, and the following topics are included:

- wood as a construction material (material and mechanical properties, wood joining and fastening, fracture mechanics problems, drying process, thermal properties);

- wood products and structures (lumber, panels, chairs, skeleton furniture, stair stringers, lattice structure, bamboo scaffoldings, carcass furniture and case furniture).

\section{NUMERICAL METHODS}

\section{NUMERIČKE METODE}

There are many practical engineering problems for which exact solutions cannot be obtained. This inability to obtain an exact solution may be attributed to either the complex nature of governing differential equations or the difficulties that arise from dealing with the boundary and initial conditions. To deal with such problems, we resort to numerical approximations. In contrast to analytical solutions, which show the exact behavior of a system at any point within the system, numerical solutions approximate exact solutions only at discrete points, called nodes. There are two common classes of numerical methods: (1) finite difference methods and (2) finite element methods. With finite difference methods, the differential equation is written for each node, and the derivatives are replaced by difference equations. This approach results in a set of simultaneous linear equations. Although finite difference methods are easy to understand and apply to simple problems, they become difficult to apply to problems with complex geometries or complex boundary conditions. This situation is also true for problems with nonisotropic material properties. In contrast, the finite ele- ment method uses integral formulations rather than difference equations to create a system of algebraic equations. Moreover, a continuous function is assumed to represent the approximate solution for each element. The complete solution is then generated by connecting or assembling the individual solutions, allowing for continuity at the inter-elemental boundaries.

\section{THE FINITE ELEMENT METHOD}

\section{METODA KONAČNIH ELEMENATA}

The basic concept in the physical FEM is the subdivision of the mathematical model into disjoint (nonoverlapping) components of simple geometry called finite elements or elements for short. The response of each element is expressed in terms of a finite number of degrees of freedom characterized as the value of an unknown function, or functions, at a set of nodal points. The response of the mathematical model is then considered to be approximated by that of the discrete model obtained by connecting or assembling the collection of all elements. The disconnection-assembly concept occurs naturally when examining many artificial and natural systems. For example, it is easy to visualize an engine, bridge, building, airplane, or skeleton as fabricated from simpler components.

\subsection{A brief history of the finite element method}

3.1. Kratka povijest metode konačnih elemenata

The origin of the modern FEM may be traced back to the early 1900 s when some investigators approximated and modeled elastic continua using discrete equivalent elastic bars. In 1941, Hrenikoff presented a solution of elasticity problems using the "frame work method". However, Courant (1943) has been credited with being the first person to develop the FEM. Courant used piecewise polynomial interpolation over triangular subregions to investigate torsion problems. The next significant step in the utilization of FEM was taken by Boeing in the 1950s when Boeing, followed by others, used triangular stress elements to model airplane wings. A book by Argyris in 1955 on energy theorems and matrix methods laid a foundation for further development in finite element studies. Turner et al. (1956) derived stiffness matrices for truss, beam, and other elements and presented their finding in 1956. The term finite element was first coined and used by Clough in 1960. Clough made the term finite element popular. During the 1960s, investigators began to apply the finite element method to other areas of engineering, such as heat transfer and seepage flow problems. In the late 1960s and early 1970s, FEM was applied to nonlinear problems and large deformations. Zienkiewicz and Cheung wrote the first book entirely devoted to the FEM in 1967. Mathematical foundations were laid in the 1970s. New element development, convergence studies, and other related areas fall in this category. In 1971, ANSYSTM was released for the first time. Then, Oden's book on linear continua appeared in 1972.

Bleich (1952), Goodier (1942), Vlasov (1961) and Timoshenko and Gere (1961) are among the researchers 
in the study of buckling of one-dimensional members. The methods of column deflection curves (Ellis et al., 1964), finite difference (Vinnakota and Aoshima, 1974) and finite integral (Brown and Trahair, 1968) were employed for solving the differential equilibrium equation for columns and beams. The Rayleigh-Ritz (Roberts, 1981) method is based on a correctly assumed deflected shape and therefore it is again limited to simple problems, where the deflected shape can be defined accurately. Based on the energy method, a discretization concept and the invention of powerful computers, the finite element received more attention in the past few decades as a more general and powerful tool for obtaining the equilibrium condition at both the linear and non-linear ranges. The excellent book by Chen and Atsuta (1977) covers various aspects of numerical methods and analysis and design of beam-columns under different loading and boundary conditions. Recently, Lindner (2000) presented a summary of the recent work on member design used mainly in German standard and Euro-code.

ANSYS ${ }^{\mathrm{TM}}$ is an engineering simulation software provider founded by software engineer John Swanson. It develops general-purpose finite element analysis and computational fluid dynamics software. While ANSYS ${ }^{\text {TM }}$ has developed a range of computer-aided engineering (CAE) products, it is perhaps best known for its ANSYSтм Mechanical and ANSYS ${ }^{\text {тм Multiphysics }}$ products.

ANSYS $^{\mathrm{TM}}$ finite element analysis enables engineers to:

- build computer models or transfer CAD models of structures, products, components, or systems;

- apply operating loads or other design performance conditions;

- study physical responses, such as stress levels, temperature distributions, or the impact of electromagnetic fields;

- optimize a design early in the development process to reduce production costs;

- do prototype testing in environments where it otherwise would be undesirable or impossible (for example, biomedical applications) (Rutgers, 2009).

The software implements equations that govern the behavior of these elements and solves them all; cre- ating a comprehensive explanation of how the system acts as a whole. These results then can be presented in tabulated or graphical forms. This type of analysis is typically used for the design and optimization of a system far too complex to be analyzed by hand. Systems that may fit into this category are too complex due to their geometry, scale, or governing equations (Theja and Krishna, 2013).

ANSYS is a comprehensive general-purpose finite element computer program that contains over 100,000 lines of code. ANSYS is capable of performing static, dynamic, heat transfer, fluid flow, and electromagnetism analyses. ANSYS has been a leading FEA program for well over 20 years. The current version of ANSYS has a completely new look, with multiple windows incorporating Graphical User Interface (GUI), pull down menus, dialog boxes, and a tool bar. Today, you will find ANSYS in use in many engineering fields, including aerospace, automotive, electronics, and nuclear. In order to use ANSYS or any other "canned" FEA computer program intelligently, it is imperative that one first fully understands the underlying basic concepts and limitations of the finite element methods (Moaveni, 2003).

ANSYSTM Mechanical and ANSYSTM Multiphysics software are non-exportable analysis tools incorporating pre-processing (geometry creation, meshing), solver and post-processing modules in a graphical user interface. These are general-purpose finite element modeling packages for numerically solving mechanical problems, including static/dynamic structural analysis (both linear and non-linear), heat transfer and fluid problems, as well as acoustic and electro-magnetic problems.

ANSYS $^{\mathrm{TM}}$ Mechanical technology incorporates both structural and material non-linearities. ANSYSTM Multiphysics software includes solvers for thermal, structural, CFD, electromagnetics, and acoustics and can sometimes couple these separate physics together in order to address multidisciplinary applications. ANSYS ${ }^{\text {TM }}$ software can also be used in civil engineering, electrical engineering, physics and chemistry. Some examples of the capabilities of ANSYSTM are shown in Fig. 1.

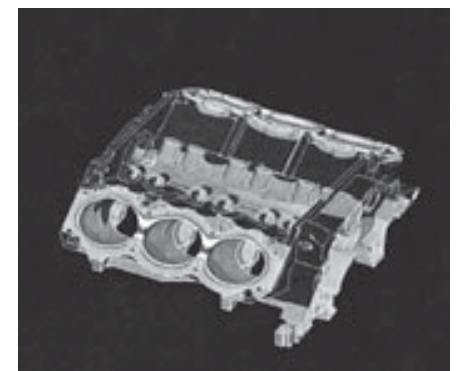

A v6 engine used in front-wheeldrive automobiles Motor v6 za automobile s prednjim pogonom

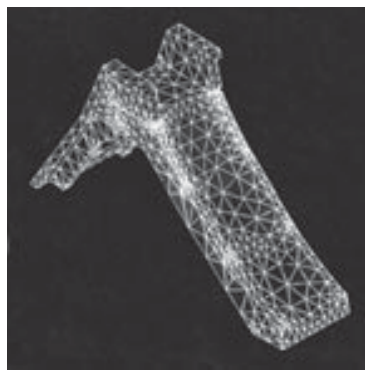

Large deflection capabilities of ANSYSTM

Mogućnosti velikog otklona programa ANSYS TM

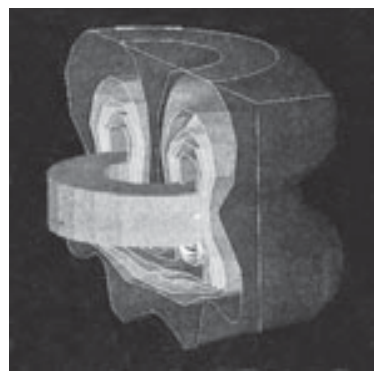

Electromagnetics capabilities of ANSYSTM

Elektromagnetne mogućnosti programa ANSYS

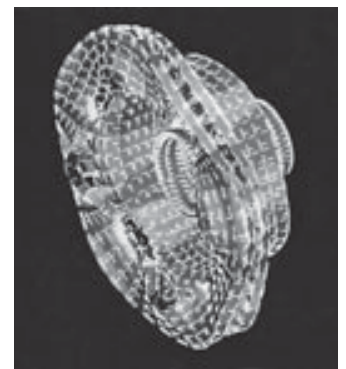

Structural Analysis Engineering Corporation Strukturna analiza

Figure 1 Examples of ANSYSTM capabilities (Moaveni, 2003)

Slika1. Primjeri mogućnosti programa ANSYSTM (Moaveni, 2003) 
In the last four decades, the FEM has become the prevalent technique used for analyzing physical phenomena in the field of structural, solid and fluid mechanics as well as for the solution of field problems.

\subsection{Basic theory}

\subsection{Osnovna teorija}

FE analysis obtains the temperatures, stresses, flows, and other desired unknown parameters in the FE model by minimizing energy functional. Energy functional consists of all the energies associated with the particular finite element model. Based on the law of conservation of energy, the FE energy functional must equal zero.

The FEM obtains the correct solution for any FE model by minimizing the energy functional. The minimum of the functional is found by setting the derivative of the functional with respect to the unknown grid point potential for zero. Thus, the basic equation for FE analysis is:

$$
\frac{\partial F}{\partial p}=0
$$

where $F$ is the energy functional and $p$ is the unknown grid point potential (in mechanics, the potential is displacement.) to be calculated. This is based on the principle of virtual work, which states that if a particle is under equilibrium, under a set of a system of forces, then for any displacement, the virtual work is zero. Each FE will have its own unique energy functional.

As shown in Table 1, in the FE displacement method, the displacement is assumed to have unknown values only at the nodal points, so that the variation within the element is described in terms of the nodal values by means of interpolation functions. Thus, within any one element, $d=N \cdot u$, where $N$ is the matrix of interpolation functions termed shape functions and $u$ is the vector of unknown nodal displacements. The strains within the element can be expressed in terms of the element nodal displacements as $e=B \cdot u$, where $B$ is the strain displacement matrix. Finally, the stresses may be related to the strains by use of an elasticity matrix (e.g., Young's modulus) as $s=E \cdot e$.

\subsection{Basic steps in the finite element method}

\subsection{Osnovni koraci metode konačnih elemenata}

The basic steps involved in any finite element analysis consist of the following:

\section{Preprocessing Phase}

1. Create and discretize the solution domain into finite elements; that is, subdivide the problem.

2. Assume a shape function to represent the physical behavior of an element; that is, a continuous function is assumed to represent the approximate solution of an element.

3. Develop equations for an element.

4. Assemble the elements to present the entire problem. Construct the global stiffness matrix.

5. Apply boundary conditions, initial conditions, loading and material information.

Solution Phase

6. Solve a set of linear or nonlinear algebraic equations simultaneously to obtain nodal results, such as displacement values at different nodes; other derived quantities, such as gradients and stresses, may be evaluated at this phase.

Post processing Phase

7. Obtain other important information. Present the results, the post processing stage deals with the presentation of results. Typically, the deformed configuration, mode shapes, temperature, and stress distribution are computed and displayed at this stage.

The role of FEM in numerical simulation is schematized in Fig. 2. Although this diagram oversimplifies the way FEM is actually used, it serves to illustrate terminology. The three key simulation steps shown are: idealization, discretization and solution. Each step is a source of errors. For example, the discretization error is the discrepancy that appears when the discrete solution is substituted in the mathematical model (FEM Modelling: Introduction, 2009).

Idealization:

Idealization passes from the physical system to a mathematical model. This is the most important step in engineering practice, because it cannot be "canned." It must be done by a human.

Discretization:

Mathematical modeling is a simplifying step. However models of physical systems are not necessarily simple to solve. They often involve coupled partial differential equations in space and time subject to boundary and/or interface conditions. Such models have an infinite number of degrees of freedom. This process divides the medium of interest into a number of small subregions and nodes.

Table 1 Physical significance of vectors $u$ and $f$ variations according to model application

Tablica 1. Fizikalno značenje promjena vektora $u$ if $f$ obzirom na model primjene

\begin{tabular}{|l|l|l|}
\hline $\begin{array}{l}\text { Application problem } \\
\text { Problem }\end{array}$ & $\begin{array}{l}\text { State (DOF) vector } \text { u represents } \\
\text { Veličine koje predočuje vektor } u\end{array}$ & $\begin{array}{l}\text { Forcing vector } \text { f represent } \\
\text { Veličine koje predočuje vektor } f\end{array}$ \\
\hline $\begin{array}{l}\text { Structures and solid mechanics / struk- } \\
\text { turna mehanika i mehanika čvrstih tvari }\end{array}$ & Displacement/ pomak & Mechanical force / mehanička sila \\
\hline Heat conduction / vodljivost topline & Temperature/ temperatura & Heat flux / tok topline \\
\hline Acoustic fluid / akustika fluida & Displacement potential / potencijal pomaka & Particle velocity / brzina čestica \\
\hline Potential flows / potencijalni tokovi & Pressure / tlak & Particle velocity / brzina čestica \\
\hline General flows / opći tokovi & Velocity / brzina & Fluxes / protoci \\
\hline Electrostatics / elektrostatika & Electric potential / električni potencijal & Charge density / gustoća punjenja \\
\hline Magnetostatics / magnetostatika & $\begin{array}{l}\text { Magnetic potential } \\
\text { magnetni potencijal }\end{array}$ & $\begin{array}{l}\text { Magnetic intensity } \\
\text { magnetni intenzitet }\end{array}$ \\
\hline
\end{tabular}




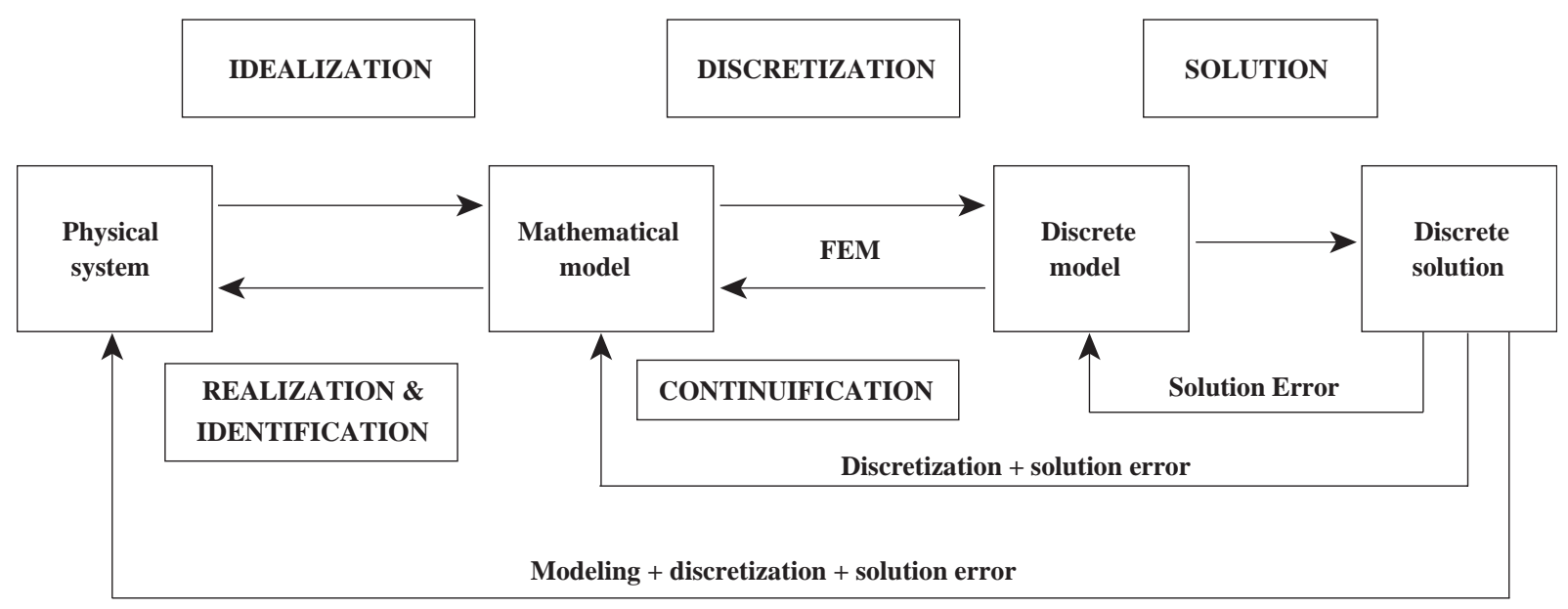

Figure 2 A simplified view of the physical simulation process, primarily useful to illustrate modeling terminology Slika 2. Pojednostavnjeni prikaz simulacije procesa, osobito primjenjiv za ilustraciju terminologije modeliranja

$1 \mathrm{D}$

2D
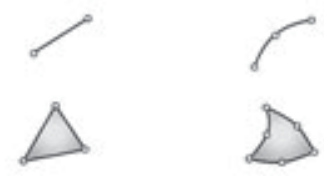

$2 \mathrm{D}$
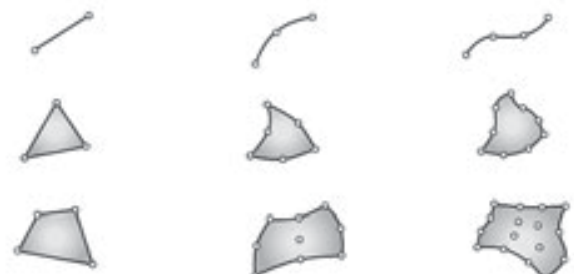

$3 \mathrm{D}$
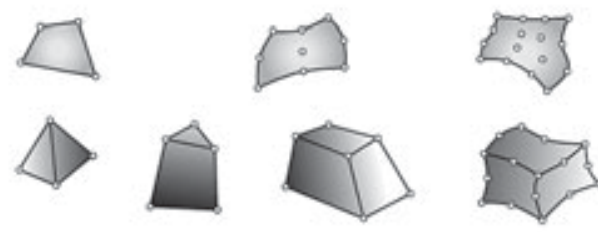

Figure 3 Higher order element nodes

Slika 3. Elementarni čvorovi višeg reda

\section{Solution:}

Solve the system of equations involving unknown quantities at the nodes (e.q. displacements).

A typical FEA on a software system requires the following information:

1. Nodal point spatial locations (geometry)

2. Elements connecting the nodal points

3. Mass properties

4. Boundary conditions or restraints

5. Loading or forcing function details

6. Analysis options

The geometry of the element is defined by the placement of the geometric nodal points. Most elements used in practice have fairly simple geometries. In one-dimension, elements are usually straight lines or curved segments. In two dimensions, they are of triangular or quadrilateral shape. In three dimensions, the most common shapes are tetrahedra, pentahedra (also called wedges or prisms), and hexahedra (also called cuboids or "bricks"). Fig. 3 Nodes are usually located at the corners or end points of elements, as illustrated in Fig. 2. In the so-called refined or higher-order elements, nodes are also placed on sides or faces, as well as possibly the interior of the element.

3.4 The use of FEA in furniture design

3.4. Primjena metode konačnih elemenata u dizajnu namještaja

A natural objective of the designer is to minimize manufacturing costs of given articles which, in turn, are connected with minimization of material consumption. This stresses the need to elaborate computer programs capable of applying numerical optimization of furniture constructions. In the case of carcass furniture, significant savings can be achieved by minimizing dimensions of the cross section of wood elements. Typical computer applications analyzing force distribution and internal stresses in construction members allow to verify the strength of a system, which was designed and dimensioned earlier or to compare several variants of the same design. Therefore, their application, in the case when a simultaneous decision concerning several dimensions of the same construction must be taken, may be difficult or even impossible. The selection of the best construction parameters can be achieved by applying numerical optimization algorithms working on mathematical models of the projected system (Dietrich, 1986).

Both scientific experience and engineering practice indicate that decision making processes in the course of solving complex designing problems require an analysis of a great number of different construction variants. These types of decision-making processes take much time and do not always result in the selection of an optimal solution. That is why deterministic or numerical optimization methods are applied in a wide range of technical areas, which assist in the selection of the best solution. One of the basic difficulties encountered during the optimization process of furniture constructions, which, in their majority, constitute statically indeterminable systems, is a variation in the distribution of internal forces affected by changes in cross-sectional dimensions of component elements. This indicates a need to develop optimization algorithms in which values of internal forces will be calculated after each change of geometrical conditions (Smardzewski and Gawroński, 2001).

Furniture design is almost always based on experience from traditions in handicraft manufacturing. No carpentry use static analyses for finding the internal forces inside the wooden members of e.g. a chair. However, some academic research groups have shown interest in this topic and the first to mention must be the work of Eckelman (1967). 
In the paper he showed that a chair could be analyzed as a structure for taking up loads. By use of strain gauges he also presented some values for the maximum moments at different parts of the chair. He stated that the rigidity-strength procedure of furniture design comprises the determination of values of outside loads affecting the construction, the establishment of the distribution of inner forces and then the calculation of dimensions of elements and constructional joints (Eckelman, 1967; Eckelman and Suddarth, 1969).

The exact analysis of furniture frames has been a computationally complex process. At present, engineering design of furniture can be accomplished by utilizing solid modeling and structural analysis software. From a practicing furniture engineer's point of view, FEM provides the most convenient tool for analyzing furniture systems. All members of the product can be modeled parametrically and required changes can readily be optimized via advantages that are provided by the solid modeling. Likewise, strength calculations of the designed product could be made by means of the computer aided structural analysis software (Kasal, 2004).

In Poland, the research seems to have been concentrated around the Poznan University. Several papers have been published and some of them dealt with FEM, and various kinds of furniture chairs. Investigations in the field of furniture were undertaken by Smardzewski, who presented algorithms and results of optimization of a chair side frame using the method of 'systematic search and random walk'. The objective of those calculations was to determine cross-sectional dimensions of scantling elements and connection dimensions, while maintaining appropriate strength parameters and minimal volume of the applied material. In the above-mentioned study, values of internal forces, calculated by means of a separate FEM processor, were used as input data for the application, which realized the optimization process (Smardzewski, 1992). Then, Smardzewski and Dzięgielewski (1997), performed construction optimization of cabinet furniture employing the method of random walk. Olsson et al. (2004) examined the furniture design and the dialogue between designers and engineers specialized in using FE tools. Researchers examined the influence of the stiffness corner joints, particularly, on case furniture deflection, and proposed a new method for linear structural analysis of the case furniture using FEA (Cai and Wang, 1993).

They asserted that the corner joints were semirigid and could be modeled by introducing a small area adjacent to the joints, where the same type of element could be used as that used for modeling the joints itself, but with a reduced modulus of elasticity $\left(E^{*}\right)$. If the same elastic properties were assumed for the elements within this area as for the whole joints, then the joint would be considered rigid. Although this model provides consistent results in terms of resultant deflections, the stress concentrations, which appear in the vicinity of the fixing components are not developed in the model in the same way as they are developed in the physical joints.
The overall structure is preferably analyzed by use of so called 'beam elements', while details such as joints can be studied more in detail by plain 'stress elements'. The joint is in the second case divided into small, but finite, rectangular parts while the rest of the structure is divided in larger pieces (Gustafsson, 1995).

Kasal and Puella (1995) have examined analytical and experimental results for chairs, sofas and book shelves. Further, they have studied the joints between different chair members in detail. A number of other researchers have also dealt with different types of furniture, e.g. cabinets, and two of them are Adanowicz, Dziegielewski (1976); Wang and Juang (1994).

Erdil (1995) included in the study the design and analysis of wood school chairs and desks based on conventional structural design methods, evaluation of the furniture by performance test equipment and procedures selected specifically for that purpose, and finally a comparison to the results obtained by performance testing and those predicted by conventional design procedures. Prototypes were tested utilizing low-cost performance testing equipment and the "cyclic stepped increasing load method". The prototype frames were structurally analyzed by means of FEM. The results showed that performance testing equipment, which was low-cost, simple, and easy to use and maintain, could be used for testing school chairs and desks, and 3-D structural analyses by means of FEM gave reasonable estimates of the overall strength of the furniture constructions. Ekström (1997); Aronsson and Lindgren (2000) studied the design of chairs with the help of FE.

Efe et al. (2003) constructed two school chairs with cylindrical mortise and tenon joints, and these were tested utilizing the "cyclic stepped increasing load method", and the specimens were structurally analyzed by means of FEM software. As a result, they determined that three dimensional structural analyses by means of FEM provided reasonable estimates of the overall strength of the frame furniture.

Smardzewski and Gawroński (2001) succeeded in integrating numerical methods of static optimization in FEM environment and developed an optimization algorithm of skeleton furniture, in which values of internal forces were determined after each step of optimization. This allowed taking into consideration the phenomenon of the alteration in the distribution of values of internal forces in a construction statically indeterminable in the result of the change of the cross section of component elements. Furthermore, the authors also reduced joints to rigid constructional nodes assuming that the rigidity of joints corresponded to the rigidity of the adjacent material.

Hrčka (1991) carried out an analysis of strength and rigidity of a wood construction connected by means of Unimot joints and employed two different approaches to the theoretical analysis of joint rigidity. The first approach assumed the introduction, into the static scheme, of semi-rigid bar elements to replace semi-rigid joints, while the second approach consisted in assigning constructional nodes appropriate reaction coefficients, which expressed the relationship between 
the deformation angle and bending moment operating in the node.

Cai et al. (1995) analyzed the strength and stiffness of the moltinject corner joints of cabinet furniture by comparison with the strength of two pin dowels corner joints. Furthermore, the deflection of cabinet furniture, whose corners were joined by the method of moltinject, was predicted reasonably in this study using FEM calculations.

Dzięgielewski and Smardzewski (1996) carried out laboratory experiments on wall angle joints in skeleton furniture and, for each type of the examined joints, determined equivalent modulus of joint elasticity. The obtained results provided, on the one hand, estimation of their rigidity and, on the other, served as data for numerical calculations of rigidity of furniture bodies. Elements with equivalent moduli of elasticity were then introduced into the static scheme of the analyzed construction to substitute real joints.

These problems were further investigated in studies, which discussed in detail principles for the calculation of connection dimensions in dowel and tenon joints on the basis of a recognized distribution of internal forces. Smardzewski (1998) carried out a research project for developing a computer program designed for rigidity/strength analysis of furniture side frames. Afterwards, he analyzed a side frame of a chair, and demonstrated that the computer program developed allows accurate, rapid, and multiple rigidity strength analysis of furniture side frames constructed of wood.

In another study, Smardzewski (2002) developed a mathematical model describing phenomena occurring in bent mortise joints prevalent in constructions of skeleton furniture, and also tried to determine factors influencing the strength of glued mortise and tenon joints. Analyses were treated with a computer assisted program prepared and developed at the Ponzan Agricultural University. According to the results obtained; shear strength of the glue utilized and compression strength of wood, of which the joints were constructed, affected the bending strength of glued mortise and tenon joints. Furthermore, it was mentioned that when members of the mortise and tenon joint were well fitted, compressing one another, stresses in the glue bond reduce and increase its strength.

Many later studies commonly employed FEM, which is based on the concept of 'rigidity matrix'. This method was also used by Gustafsson (1995) in the optimization process of the height position of a chairconnecting member. The author compared successive variants of the optimized construction assuming the maximum bending moment affecting the frame as the optimization criterion.

The elaborated model was verified qualitatively in the next study in which the problem of buckling of the compressed constructional elements was analyzed in detail. In a similar study, he prepared a simple birch chair and tested its strength under various loads, to which the chair could be exposed to during service. Furthermore, he determined stresses at various nodes with the FEM by modeling the chair. He has pointed out that the test results and data analyses were reasonably coherent with Gustafsson (1996a). Moreover, Gustafsson (1996b) compared the results of numerical calculations with the results of laboratory measurements of the deformed piece of furniture whose model was prepared on the basis of results of optimization calculations and arrived at the conclusion that, in many cases, the solution obtained with the aid of the applied computer program portrayed the true state of deformations and stresses. The observed numerical discrepancies were attributed to inexactitudes of laboratory tests resulting from technical problems, on the one hand, and, on the other, to differences in wood strength features during compression and tension, which were not taken into consideration in a typical FEM algorithm.

Nicholls and Crisan (2002) analyzed the stress and strain states in doweled and minifix type corner joints of the case furniture by using the FEM. As a result, they stated that the stress concentration areas in the models are developed as in the physical joints, and the stress-strain state in the corner joints can be accurately predicted. All the models were designed using ANSYS ${ }^{\text {TM }}$ Parametric Design Language (APDL), which allows FEMs to be constructed in terms of parameters. In this way design changes can be made easily to achieve an optimum design.

The products can be designed using solid models in computer aided design (CAD) programs. These models can also be used for further studies with FE calculations. Stairs, flooring, wood products and furniture are examples of products that can have a complex three-dimensional geometry, which makes it preferable to use three-dimensional models (Pousette, 2007).

Salokangas (2003) used a 3-D CAD model of a complex, irregular lattice structure for a wood tower in Helsinki Zoo. The complex geometry data were imported into a FE model for structural analysis using threedimensional linear beam elements to check the ultimate and serviceability limit states for applied loads.

One of the references is a study of the structural performance of wood-based stair stringers with fullscale tests by Lam et. al (2004). They tested stair systems and also used a commercial FE package to model a stair system for further insight into its structural response. They concluded that the FE program can be used to model stair systems with configurations and material properties other than the tested ones. Comparison of results of FE analysis of an entire wood spiral staircase to full-scale laboratory tests showed that a three dimensional solid model of the stair as a complete part was stiffer than the actual stair (Pousette, 2003).

The deformation behavior of wood around moment-resisting joints was analyzed using digital image correlation method (DIC) and FEM. The joints consisted of four drift-pins. The distribution of the strain perpendicular to grain and the shear strain parallel to the grain were examined around each drift-pin to evaluate the large deformed area and the location of initial failure. Areas of large compression strain perpendicular to the grain and large shear strain were observed in the predicted loading area of each drift-pin. Large ten- 
sile strain perpendicular to the grain was observed at the area close to the loading (contacting) area of the drift-pins, and the tension area was partly overlapped with the area of large shear strain. The overlapped area coincided with the location of initial cracks propagated parallel to the grain. The numerical results by FE analysis were compared with the experimental results obtained with DIC and they showed good agreement with each other (Seiichiro and Minoru, 2002).

A modified structural design for wooden school desks and chairs was proposed, in order to improve their performance in terms of functionality, convenience and safety. The modification was proposed based on a structural static analysis of the furniture. Analytical models of a desk and chair in a two-dimensional system of the FEM were first drawn up to simulate their mechanical behaviors, under the loading conditions specified by the Japanese Industrial Standard, JIS S1021. In this FEM simulation, wood is treated as an orthotropic material. Since the Hoffman Failure Criterion could be essentially modified to allow unequal maximum allowable stresses in tension and compression, such as in timber, it was used to examine the safety of the newly designed wooden desk and chair. Analysis of the distribution of Hoffman Failure Criterion indices in the models of a desk and chair revealed the stress concentration sections and the corresponding allowable stress levels. The structural performance of the modified desk and chair designs were analyzed repeatedly until their load bearing capacity fell within the acceptable limits. Improvement in the existing designs of wooden desks and chairs will make it possible to convert low grade logs, such as thinning materials, into environmentally and ecologically friendly school facilities (Yang et al. 2002).

The method of finite elements was applied by Smardzewski (1990) in his computer application of Panda-1 utilized to analyze the construction of carcass furniture with symmetrical side frames.

Blanchet et al. (2006) demonstrated the suitability of the FEM in the design process of new engineered flooring and stated that their work confirmed the potential of the FE method for product design of such products.

The aim of another study was to use FEM as a tool to analyze microwave scattering in wood and to verify the model by measurements with a microwave scanner. A medical computed tomography scanner was used to measure distribution of density and moisture content in a piece of Scots pine (Pinus sylvestris L.). Dielectric properties were calculated from measured values for cross sections from the piece and used in the model. Images describing the distribution of the electric field and phase shift were obtained from the FEM simulation. The model was verified by measurements with a scanner based on a microwave sensor. The results show that simulated values correspond well to measured values. Furthermore, discontinuities in the material caused scattering in both the measured and simulated values. The greater the discontinuity in the material, the greater was the need for computational power in the simulation (Lars et al., 2006).
The equations of two-dimension heat transfer processes in wood were deduced by using Galerkin's Method of Weighted Residual Method of FEM in Cai and Chang's paper (1995). The heat transfer processes were calculated by using computer program according to the heating case.

\subsection{Examples of FEM models used in wood products}

3.5. Primjeri primjene FEM modela za drvne proizvode

FE calculations were made with 3D solid models in IDEAS Anonymous (1998). The element type was 8-node brick elements (linear hexahedral elements). In the models, the treads and the spacers of the center pole were connected with contact elements (Fig. 4). Linear elastic calculations were made, and the contact elements were linear (Pousette, 2007).

In another study, the material is represented as an array of nodes connected by a network of discrete beam or spring elements. Fig. 5 shows a possible dis-

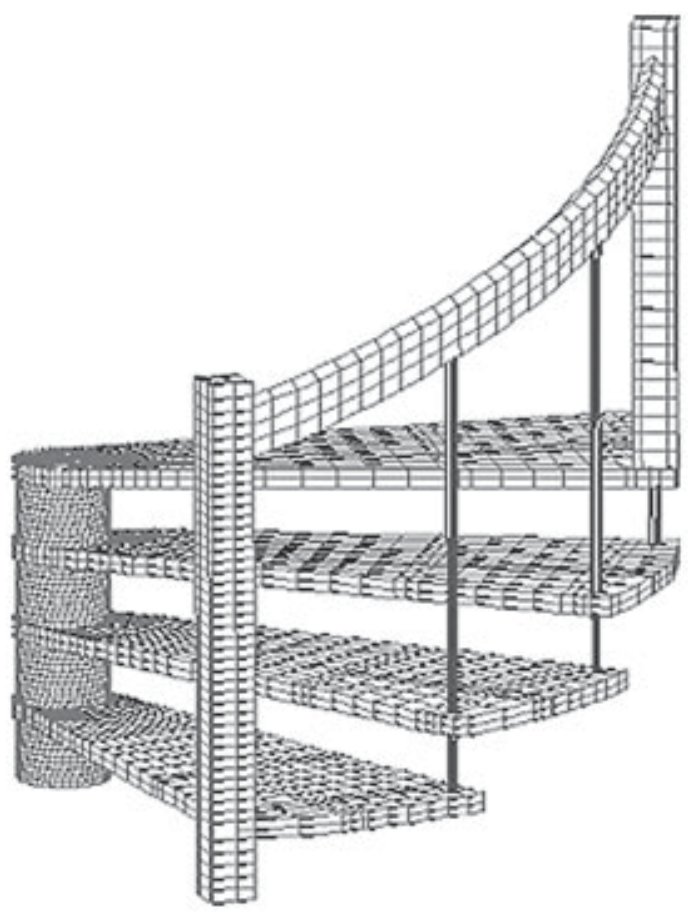

Figure 4 Contact elements with linear elastic calculations Slika 4. Kontaktni elementi s linearnim elastičnim izračunima

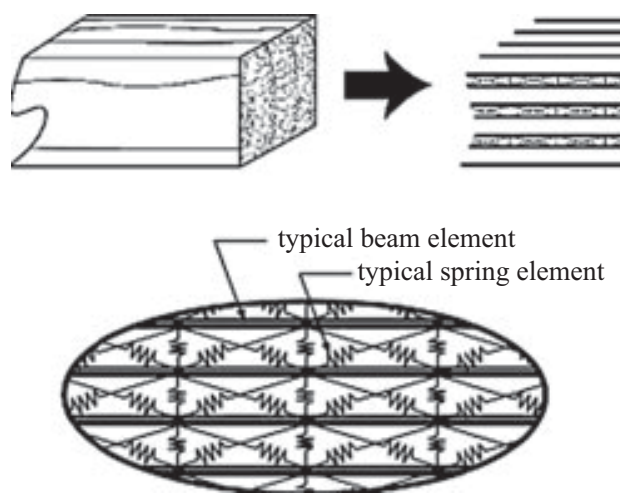

Figure 5 Discrete beam and spring elements Slika 5. Zasebni elementi grede i opruge 


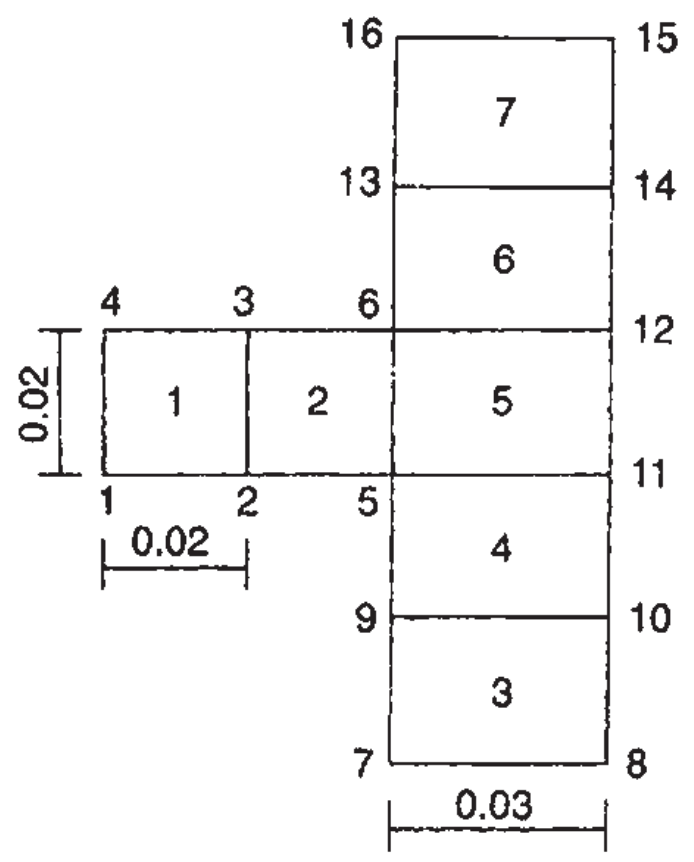

Figure 6 Part of finite element mesh for the seat and back rail joint

Slika 6. Dio mreže konačnih elemenata za spoj sjedala i naslona

cretization appropriate for wood. The longitudinal wood cells are represented by beam elements (large horizontal elements in the figure) while a network of diagonal spring elements simulates their connectivity. The chosen size of a lattice cell in the specific example corresponds to a bundle of cells so that the modeling is at the scale of wood growth rings. In order to account for pre-existing heterogeneities, disorder of wood ultra structure is introduced via statistical variation of ele-

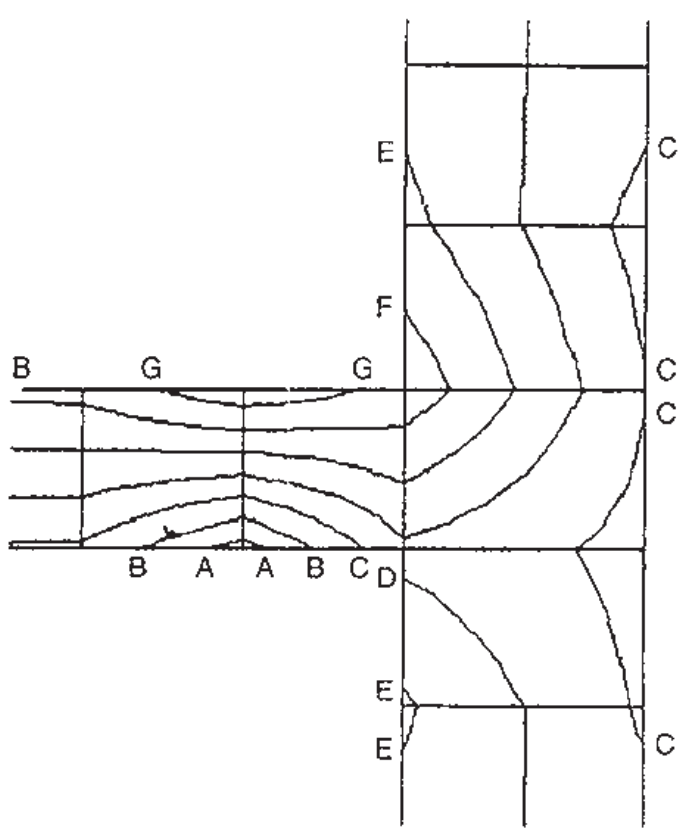

Figure 7 Stress in horizontal direction according to FEM calculations

Slika 7. Naprezanje u vodoravnom smjeru prema izračunima FE metodom ment stiffness and strength characteristics. Stiffness and strength characteristics can be assumed to fit a Gaussian distribution with specified mean and standard deviation (Vasic et al., 2005).

A theoretical study using advanced FE analysis of one element per member was reported by Chan to assess the load carrying capacities of bamboo scaffoldings (Chan et al., 1998).

In his study, Gustafsson (1997) showed how to analyze and design a chair with FEM, and gave stress diagrams and test results of the real size ash wood chair. The connection between the seat and back rails have also been studied by use of FEM method, the one with plain stress elements. The structure was then divided into thirteen elements with 26 nodes, each located in the corners of the elements; Fig. 6 shows a part of the structure. The result of the FEM analysis showed that the maximum compression stress in the horizontal direction, i.e. $-38.0 \mathrm{MPa}$, occurred just above node 2 . Maximum tension with almost the same absolute value was found just under node 3 and around node 6. Fig. 7 shows that $A$ equals -30.0 , B equals -20.0 and $G+30.0$ $\mathrm{MPa}$, respectively.

Semi-rigid joints used in the tests were modeled using ANSYS ${ }^{\mathrm{TM}}$. The stiffness obtained for the 100 $\mathrm{mm}$ wide corner joint, with one fixing element was used to determine the torsional stiffness in all models. A good correlation was obtained between experimental deflections and analytical results. Fig. 8 shows the distribution of Von Mises stresses for the two-dowel corner joint of $100 \mathrm{~mm}$ width and $18 \mathrm{~mm}$ thick, which was clamped at one end and subjected to an external load (F) of $40 \mathrm{~N}$ at the free end. The torsional stiffness used for the fixing components was $k_{9}=301,051 \mathrm{~N} \mathrm{~mm} / \mathrm{rad}$ (Nicholls and Crisan, 2002).

In principle, this is an element that has two coincident nodes (i.e. they have the same location in space), however, each of them is connected separately to the links of the joint. These two nodes are connected to each other by an imaginary pin.

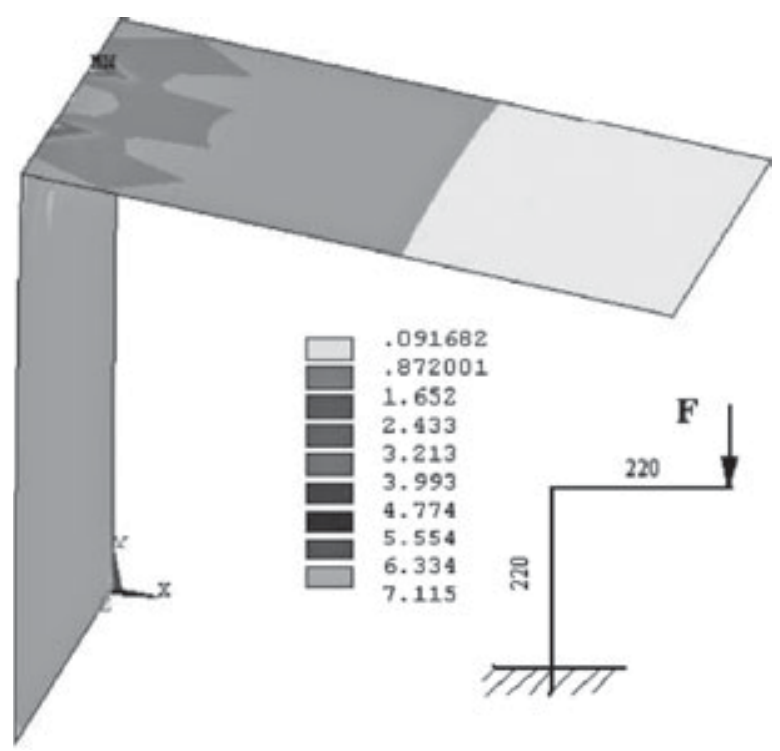

Figure 8 Distribution of Von Mises stress Slika 8. Raspodjela Von Misesovih naprezanja 


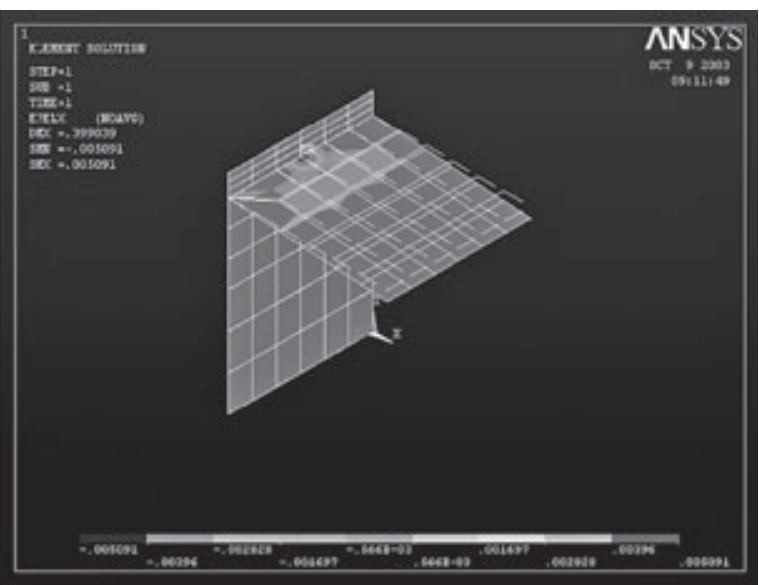

Figure 9 Loading simulation

Slika 9. Simulacija opterećenja

In other studies, brief information is given about the method and doweled furniture corner joints are modeled using FEM method. The models were analyzed using ANSYS ${ }^{\text {TM }}$ commercial software (Güntekin, 2002). Loading simulation is shown in Fig. 9.

Efforts were made to develop a numerical evaluation method of the strength and durability of furniture using a chair for the purpose of quality control, a new product design. The objective of this research is to assess strength of laminated bamboo chair under static and dynamic loading and perform drop test analysis. The simulations are set up using nonlinear dynamic FE software, which is equipped with both implicit and explicit solvers. This virtual testing result focused on the improved design and development of laminated bam-

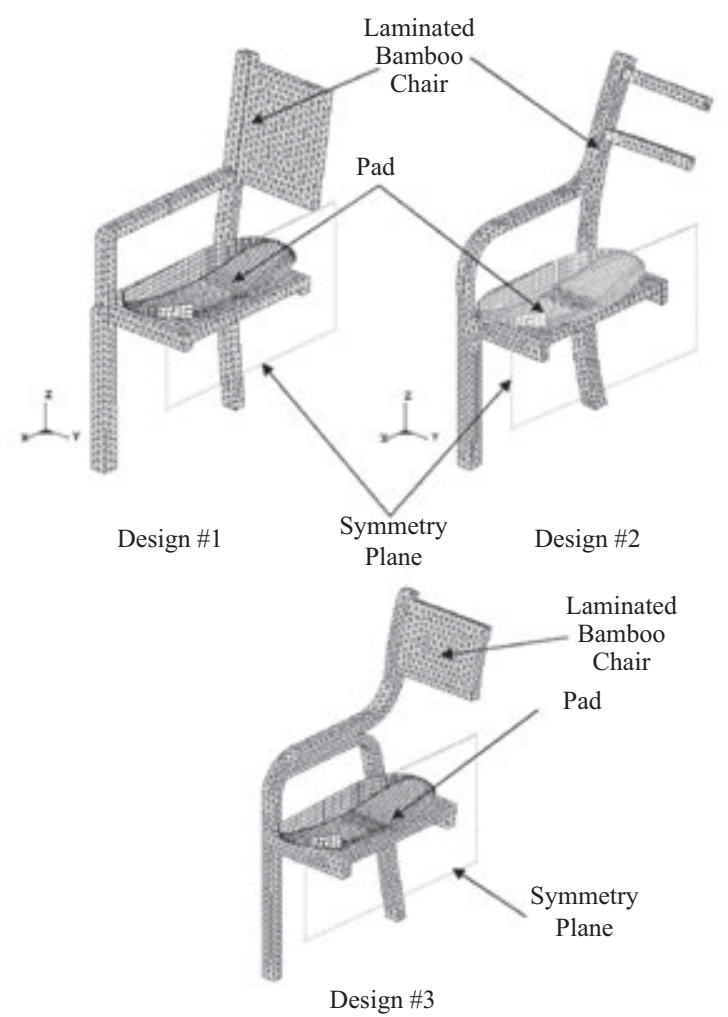

Figure 10 Isometric view of FEA models in static analysis Slika 10. Izometrijski pogled na FEA modele pri statičkoj analizi

boo chair through virtual testing (Laemlaksakul, 2008). The static loading simulation is conducted using the implicit solver. The model setup for static loading simulation is illustrated in Figures 10, 11 and 12.

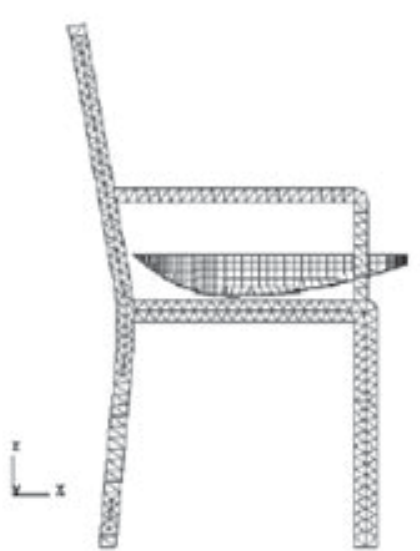

Design \#1

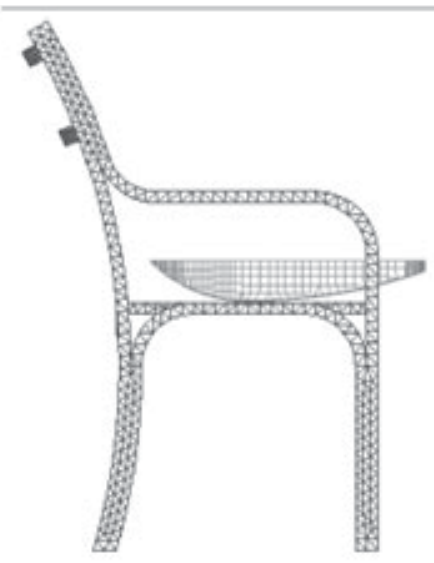

Design \#2

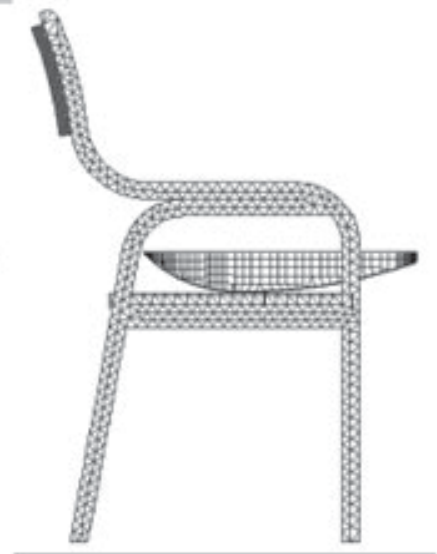

Design \#3

Figure 11 Side view of FEA models in static analysis

Slika 11. Bočni pogled na FEA modele pri statičkoj analizi

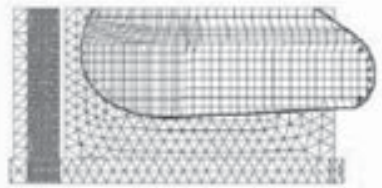

Design \#1

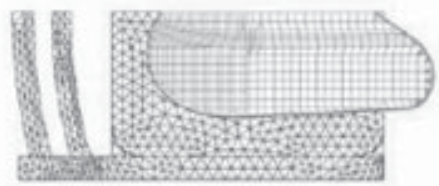

Design \#2

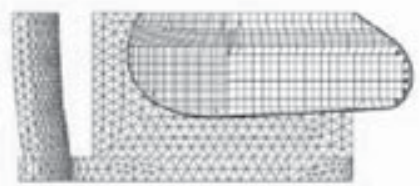

Design \#3

Figure 12 Top view of FEA models in static analysis

Slika 12. Pogled odozgo na FEA modele pri statičkoj analizi 


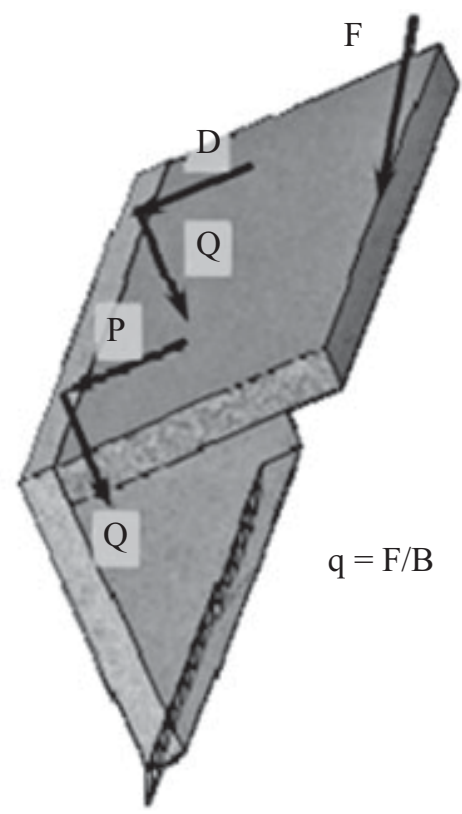

Figure 13 Dimensions of samples and direction of load (grid and boundary $L=200 \mathrm{~mm}, A=125 \mathrm{~mm}$ (joint spacing), conditions) of a half of corner connection sample $\mathrm{B}=200$ $\mathrm{mm}, \mathrm{g}=18 \mathrm{~mm}$

Slika 13. Dimenzije uzoraka i smjer opterećenja (mreža i rubni uvjeti: $L=200 \mathrm{~mm}, A=125 \mathrm{~mm}$ ) polovice kutnog spoja $B=200 \mathrm{~mm}, g=18 \mathrm{~mm}$

Another study presents strength problems of corner connections for $M D F$ boards, resulting from loads causing the closure of the connection. The effect of excess load is the destruction of the connection as a result of edge delamination. The objects of experimental studies were models of wall corner connections of MDF boards with two invis joints (Fig. 13). Samples were subjected to a complex state of load of a quasistatic nature (traverse movement velocity of $2 \mathrm{~mm} /$ min). Solid linear brick and solid linear wedge elements were used for the purpose of digitization (Fig. 14). Stress patterns were obtained for the analyzed cases. The results show that very small loads (29 N) may cause local board delamination (Mostowski and Sydor, 2006).

\section{RESULTS}

\section{REZULTATI}

The basic premise of modern engineering is that models can be used to extrapolate beyond the range of test data. Therefore, if complex physical processes and phenomena related to fracture in wood are understood for representative situations, numerical models can be built to represent those processes beyond the range of those representative situations. FEA and other numerical analysis techniques can, therefore, never be a total replacement for experimental observations. They are a powerful adjunct that has to be allied with experimental observation and material characterization.

It is commonly accepted that the structural design of most furniture, the box-type furniture in particular, is usually based on experience or tradition in

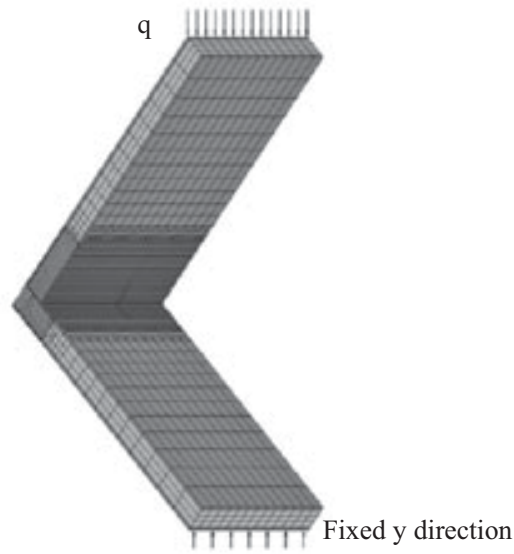

Figure 14 FEM model

Slika 14. FEM model

handicraft manufacturing. Development of new products in the joinery industry is usually based on traditional craftsmanship and testing of prototypes. FE modeling can be a valuable support in the process of product development.

\section{CONCLUSION \\ 5. ZAKLJUČAK}

Computer software, which has already taken roots in machine and construction industries, still finds a limited application in furniture industry. A majority of manufactured furniture continues to be designed exclusively on the basis of craftsmanship and engineering practice. However, pressures resulting from quality and reliability requirements of final products make it more and more necessary to pay increasingly more attention to rigidity-strength optimization of dimensioning of furniture elements and constructional joints.

This paper focused on strength analysis of wood products, specifically furniture structures by FEA methods. FE simulations can enable faster, less costly, and more optimized product development, as well as examinations of product performance that would not be possible even using very detailed prototypes. In the wood industry, these tools have not been much used, but in other industries such as the aerospace and automobile industry, they have been much used for many years. Wood is a more complicated material to model than steel, and studies of wood product design with FE models have been published in the academic world.

\section{REFERENCES}

6. LITERATURA

1. Adanowicz, V. J.; Dziegielewski, S., 1976: Prüfung und analyse geklebter verbindungen an möbeln. Holztechnologie, 17(2): 97-100.

2. Anonymous, 1998: Ideas master series 6. Structural Dynamics Res. Corporation. SDRC. Milford. Ohio, 45150. USA.

3. Argyris, J. H., 1955: Energy theorems and structural analysis. Aircraft Engineering, 27: Feb.-May. 
4. Aronsson, S.; Lindgren, C. M., 2000: Produktutveckling av möbler med hjälp av FEM (Product development of furniture with aid of FEM). Chalmers Univ. of Tech. Göteborg. Sweden (in Swedish).

5. Bathe, K. J., 1996: Finite element procedures. Prentice Hall, New Jersey, USA.

6. Blanchet, P.; Cloutier, A.; Gendron, G.; Beauregard, R., 2006: Engineered wood flooring design using the finite element method. Forest Prod J. 56(5): 65.

7. Bleich, F., 1952: Buckling strength of metal structures. New York: McGraw-Hill.

8. Brown, P. T.; Trahair, N. S., 1968: Finite integral solution of differential equations. Civil Eng. Trans, Inst Eng, Sydney, Australia, 10(2):193-196.

9. Cai, L.; Chang, J., 1995: Using FEM to analyze heat transfer processes in wood. Holz als Roh-und Werkstoff. ISSN 0018-3768, 53(3): 183-186. http://dx.doi.org/10.1007/BF02716421.

10. Cai, L.; Wang, F., 1993: Influence of the stiffness of corner joints on case furniture deflection. Holz Roh-Werkstoff, 51: 406-408. http://dx.doi.org/10.1007/BF02628238.

11. Cai, L.; Wang, F.; Tan, H., 1995: Study on the strength of moltinject corner joints of furniture. Holz als Roh-und Werkstoff, 53(6): 385-388. http://dx.doi.org/10.1007/ s001070050113.

12. Chan, S. L.; Wong, K. W.; So, Y. S.; Pon, S. W., 1998: Empirical design and structural performance of bamboo scaffolding. Proceedings of the Symposium on Bamboo and Metal Scaffoldings, The Hong Kong Institution of Engineers.

13. Chandrupatla, T.; Belegundu, A. D., 1991: Introduction to finite elements in engineering. Prentice Hall, Inc. New Jersey.

14. Chen, W. F.; Atsuta, T., 1977: Theory of beam-columns. New York: McGraw-Hill, (vol. 1-2).

15. Clough, R. W., 1960: The finite element method in plane stress analysis. Proceedings American Society of Civil Engineers, 2d Conference on Electronic Computation, Pittsburgh, Pennsylvania, 23: 345-378.

16. Cook, R. D., 1981: Concepts and applications of finite element analysis. Wiley \& Sons, New York, USA.

17. Courant, R., 1943: Variational methods for the solution of problems of equilibrium and vibrations. Bulletin of the American Mathematical Society, 49: 1-23 http://dx.doi. org/10.1090/S0002-9904-1943-07818-4.

18. Dietrich, M., 1986: Podstawy konstrukcji maszyn [Basics of machines' construction]. PWN. Warszawa. [in Polish].

19. Dzięgielewski, S.; Smardzewski, J., 1996: Moduł sprężystości połączeń a sztywność mebli skrzyniowych - Analiza numeryczna [Modulus of eleasticity of joints versus rigidity of case furniture - numerical analysis]. VIII Sesja Naukowa Badania dla Meblarstwa. Poznań 23-47. [in Polish].

20. Eckelman, C. A., 1967: Chair frame analysis and design. For. Prod. J., 17: 100-106.

21. Eckelman, C. A.; Suddarth, S., 1969: Analysis and design of furniture frames. Wood Science and Technology, 3: 239- 255 . http://dx.doi.org/10.1007/BF00367215.

22. Efe, H.; Erdil, Y. Z.; Kasal, A., 2003: Optimization of furniture systems with finite element method (FEM) in engineering design of furniture. Technical Education Faculty, Gazi Univ., Ankara, Turkey.

23. Ekström, R., 1997: Konstruktionsdesign av möbler med FEM (Design of furniture with FEM). Lund Inst. of Tech. Lund. Sweden, [in Swedish].
24. Ellis, J. S.; Jury, E. J.; Kirk, D. W., 1964: Ultimate capacity of steel columns loaded biaxially EIC-64-BR and STR2. Trans, Eng Inst Canada, 7(2):3-11.

25. Erdil, Y. Z., 1995: Integrated product engineering and performance testing of furniture. PhD. Thesis. Purdue Univ., West Lafayette, IN.

26. Goodier, J. N., 1942: Torsional and flexural buckling of bars of thin-walled open section under compressive and bending loads. J Appl Mech, ACSE, 64.

27. Güntekin, E., 2002: Experimental and theoretical analysis of the performance of ready-to-assemble furniture joints constructed with medium density fiberboard. $\mathrm{PhD}$ Thesis, State Uni. of New York.

28. Gustafsson, S. I., 1995: Furniture design by use of the finite element method. Holz als Roh- und Werkstoff, 53(4): 257-260 http://dx.doi.org/10.1007/s001070050084.

29. Gustafsson, S. I., 1996a: Finite element modelling versus reality for birch chairs. Holz als Roh-und Werkstoff, 54(5): 355-359.

http://dx.doi.org/10.1007/s001070050200.

30. Gustafsson, S. I., 1996b: Stability problems in optimised chairs. Wood Sci. Technol. 39: 339-345. http://dx.doi. org/10.1007/BF00223553.

31. Gustafsson, S. I., 1997: Optimishing ash wood chairs. Wood Sci. Technol. 3: 291-301. http://dx.doi.org/10.1007/BF00702616.

32. Hrčka, I., 1991: Príspevok k statickému pôsobeniu spoja unimont [Statical analysis of unimont connection]. Drevárski Viskum, 128: 17-33. [In Slovakian].

33. Hrenikoff, A., 1941: Solution of problems in elasticity by the frame work method. Journal of Applied Mechanics, Transactions of the ASME, 8: 169-175.

34. Kasal, A., 2004: The strength performance of the chair frames constructed of solid wood and wood composites. $\mathrm{Ph}$. D. thesis. Inst of Sci. and Tech., Gazi Univ., Ankara, Turkey.

35. Kasal, B.; Puella, S. V., 1995: Development of analytical models for furniture. Technical report 95-01, Furniture Manufacturing and Management Center, North Carolina State University.

36. Laemlaksakul, V., 2008: Innovative design of laminated bamboo furniture using finite element metod. $\operatorname{Vol}(2): 3$.

37. Lam, F.; Lee, G.; Yan, H.; Gu, J.; Saravi, A. A., 2004: Structural performance of wood-based stair stringers. Forest Prod J., 54(4): 39-44.

38. Lars, H.; Anna-Lena, A.; Nils, L.; Olle, H., 2006: Finite element modeling (FEM) simulation of interaction between wood and microwaves. J. Wood Sci., (52)5: 406410 http://dx.doi.org/10.1007/s10086-005-0794-8.

39. Lindner, J., 2000: Stability of structural members. J Construct Steel Res, 55:29-44 http://dx.doi.org/10.1016/S0143-974X(99)00076-0.

40. Moaveni, S., 2003: Finite element analysis: theory and application with ANSYS ${ }^{\mathrm{TM}}$. Second Edition Pearson Education.

41. Mostowski, R.; Sydor, M., 2006: Board delamination with edge breakage as one of failure mechanisms in semi-rigid corner connections - Numerical Analysis.

42. Nicholls, T.; Crisan, R., 2002: Study of the stress-strain state in corner joints and box-type furniture using FEA. Holz als Roh- und Werkstoff, 60: 66-71. http://dx.doi.org/10.1007/s00107-001-0262-0.

43. Oden, J. T., 1972: Finite elements of nonlinear continua, New York: McGraw-Hill.

44. Olsson, P., Eriksson, P.; Olsson, K., 2004: Computersupported furniture design at an early conceptual Stage. Inter Journal of Design Computing 7. 
45. Pousette, A., 2003: Full-scale test and finite element analysis of a wooden spiral staircase. Holz als Roh-und Werkstoff, 61(1): 1-7. http://dx.doi.org/10.1007/s00107-002-0345-6.

46. Pousette, A., 2007: Finite element analysis and test of join at the center pole of a wooden spiral stair. Forest Prod J. 57(5): 25-29.

47. Roberts, T. M., 1981: Second order strains and instability of thin walled bars of open cross -section. Int J. Mech Sci, 23: 297-306 http://dx.doi.org/10.1016/0020-7403(81)90033-3.

48. Salokangas, L., 2003: Wooden observation tower. Helsinki, Finland. Structural Engineering Inter 3/160-162.

49. Seiichiro, U.; Minoru, M., 2002: Wood and wood based materials. fracture analysis of wood in moment-resisting joints with four drift-pins using digital image correlation method (DIC). Journal of the Society of Materials Science, 51(4): 367-372.

http://dx.doi.org/10.1007/s00226-005-0026-9.

50. Smardzewski, J., 1990: Numerical analysis of furniture construction using finite elements method. Przem. Drzewn. 41(7): 1-5. [In Polish]. http://dx.doi.org /10.1007/BF00702895.

51. Smardzewski, J., 1992: Numeryczna optymalizacja konstrukcji krzesel. Przemysl Drzewny, No 1.

52. Smardzewski, J., 1998: Numerical analysis of furniture constructions. Wood Science and Technology, 32(4): 273-286. http://dx.doi.org/10.1007/BF00702895.

53. Smardzewski, J., 2002: Strength of profile- adhesive joints, Wood Science and Technology. 36: 173-183. http://dx.doi.org/10.1007/s00226-001-0131-3.

54. Smardzewski, J.; Dzięgielewski, S., 1997: Computer assisted optimization of selected cross-sections of furniture elements. X Sesja Naukowa Badania dla Meblarstwa. Poznań, 9-21.

55. Smardzewski, J.; Gawroński, T., 2001: FEM algorithm of chair optimisation. Electronic Journal of Polish Agriculture Universities. Vol. 4(2).

56. Tanvir, W.S.; Utku, M., 1987: Sonlu eleman yönteminde varyasyonlu yaklaşım. Orta Doğu Teknik Üniversitesi, Anadolu Üniversitesi, Eskişehir.

57. Theja, M. S.; Krishna, M. V., 2013: Static and thermomechanical analysis of disc brake. Global Journal of Engineering, Design \& Technology, Vol(2)3:12-18.

58. Timoshenko S. P.; Gere J. M., 1961: Theory of elastic stability, 2nd ed. New York: McGraw-Hill.

59. Turner, M. J.; Clough, R. W.; Martin, H. C.; Topp, L. J., 1956: Stiffness and deflection analysis of complex struc- tures. Journal of Aeronautical Science, 23(9): 805-824 http://dx.doi.org/10.2514/8.3664.

60. Vasic, S.; Smith, L.; Landis, E., 2005: Finite element techniques and models for wood fracture mechanics. Wood Sci. Tech., 39: 3-7. http://dx.doi.org/10.1007/s00226-004-0255-3.

61. Vinnakota, S., Aoshima, Y., 1974: Inelastic behaviour of rotationally restrained columns under biaxial bending. Struct. Eng, 52(7): 235-255.

62. Vlasov, V. Z., 1961: Thin walled elastic beams, 2nd ed. Washington DC: National Science Foundation.

63. Wang, S. Y.; Juang, H. B., 1994: Structural behaviour of various joints in furniture components made of softwood laminated veneer lumber. Mokuzai Gakkaishi, 40(9): 911-921.

64. Yang, P.; Michiyo, T.; Hayato, M.; Yasuo, O., 2002: Structural design improvement of wooden school desks and chairs based on the hoffman failure criterion. Journal of the Japanese Society of Technology Education, 44(3): 133-138.

65. Zienkiewicz, O. C.; Cheung Y. K., 1967: The finite element method in structural and continuum mechanic, London: McGraw-Hill.

66. Zienkiewicz, O. C.; Taylor, R. L., 1988: The finite element method: vol. 1-basic formulation and linear problems. McGraw Hill, London.

67. Zienkiewicz, O. C.; Taylor, R. L.,1989: The finite element method: vol. 2-solid and fluid mechanics, dynamics and non-linearity. McGraw Hill, London.

68. ***2009: Rutgers, ANSYS, http://coewww.rutgers.edu/ ecs/software.php?script=ansys.

69. ***2009: FEM Modelling: Introduction, http://www. colorado.edu/engineering/CAS/courses.d/IFEM.d/ IFEM.Ch06.d/IFEM.Ch06.pdf .

\section{Corresponding address:}

\section{Professor NURGUL TANKUT, Ph.D.}

Department of Forest Industry Engineering

Faculty of Forestry

Bartin University

74100, Bartin, TURKEY

E-mail: ntankut@bartin.edu.tr 